The correct method of applying these concepts statistically to a collection of particles is indicated as follows. If the particles have no inherent tendency to a needle- or plate-like form, it follows that those with an acicularity coefficient of $n$ and $1 / n$ will occur with the same frequency, and hence, for any one value of the isoproportionality coefficient, the sum of the values of $a: b$, and the sum of the values of $b: c$ will be equal; that is

$$
\overline{a: b} \div \overline{b: c}=1 \text {. }
$$

Any inherent tendency to needle- or plate-like form will modify this value accordingly, and we therefore define a quantity, the acicularity factor, as

$$
\text { acicularity factor }=\overline{a: b} \div \overline{b: c} \text {, }
$$

which is equal to the acicularity coefficient of a mean particle averaged in the special way involved in this definition. This derivation is applicable severally to groups of particles having every possible value of the isoproportionality coefficient, and therefore is applicable to any group of particles whatever, providing it be sufficiently large.

For statistical use, the isoproportionality coefficient will similarly give place to the isoproportionality factor, defined as

$$
\text { isoproportionality factor }=\overline{x: y} \text {, }
$$

where $x: y$ is the smaller of the two ratios $a: b, b: c$, for each individual particle.

Field Cottage,

E. J. W. WhITTAKer.

Windlehurst Road,

High Lane,

Stockport.

Dec. 14.

\section{Boron and Strontium in New Zealand Coal Ashes}

Atrention has been directed by V. M. Goldschmidt ${ }^{1}$ to the occurrence of minor elements in coal ashes. During the complete analysis of ash of Waikato coal examined in connexion with clinkering troubles, Mr. F. T. Seelye, chief chemist at the Dominion Laboratory, New Zealand, noted a high boron content. The Coal Survey Division then undertook an examination to determine the distribution of boron in New Zealand coal ashes. Boron was present in highest amount in Waikato coals, but was also present in smaller percentages in all New Zealand coals.

The accompanying table sets out the maximum and average percentages of boron in each coalfield. The factor of enrichment of boron in coal ashes has been worked out as in Goldschmidt's paper, by comparing the percentage of boron in coal ash with the percentage of boron in the earth's crust taken as 0.0003 .

Another element occurring in unusual amounts is strontium. Strontium has been determined by a spectrographic method similar to that described by Wilson and Fieldes ${ }^{2}$, but modified by them to permit the determination of strontium directly on the ash, without separation of lime and strontia (unpublished method).

\begin{tabular}{|c|c|c|c|c|c|}
\hline Coalfleld & Class of coal & $\begin{array}{l}\text { Maxi- } \\
\text { mum } \\
\% \text { boron }\end{array}$ & $\begin{array}{l}\text { Average } \\
\% \text { boron }\end{array}$ & $\begin{array}{l}\text { Facto } \\
\text { enrich } \\
\text { Maxi- } \\
\text { mum }\end{array}$ & $\begin{array}{l}\text { ors of } \\
\text { ment } \\
\text { Aver- } \\
\text { age }\end{array}$ \\
\hline $\begin{array}{l}\text { North } \\
\text { Auckland } \\
\text { Waikato } \\
\text { Taranaki } \\
\text { Westport } \\
\text { Reefton } \\
\text { Greymouth } \\
\text { Otago } \\
\text { Kaitangata } \\
\text { Southland } \\
\text { Chatham } \\
\text { Islands } \\
\text { Gold- } \\
\text { schmidt's } \\
\text { flgure for } \\
\text { coalashes } \\
\text { rich in } \\
\text { boron }\end{array}$ & $\begin{array}{l}\text { Sub-bituminous } \\
\quad,, \\
\text { Bituminous } \\
\text { Sub-bituminous } \\
\text { Bituminous } \\
\text { Lignite } \\
\text { Sub-bituminous } \\
\quad,, \\
\text { Peat }\end{array}$ & $\begin{array}{l}0.21 \\
1.51 \\
0.73 \\
0.29 \\
0.86 \\
0.15 \\
0.14 \\
0.44 \\
0.24 \\
0.10\end{array}$ & $\begin{array}{l}0 \cdot 21 \\
1.09 \\
0 \cdot 58 \\
0 \cdot 29 \\
0 \cdot 86 \\
0 \cdot 07 \\
0 \cdot 11 \\
0 \cdot 39 \\
0 \cdot 18 \\
0 \cdot 10\end{array}$ & $\begin{array}{r}700 \\
5,000 \\
2,400 \\
1,000 \\
3,000 \\
500 \\
500 \\
1,500 \\
800 \\
300\end{array}$ & $\begin{array}{r}700 \\
3,600 \\
1,900 \\
1,000 \\
3,000 \\
250 \\
400 \\
1,300 \\
600 \\
300\end{array}$ \\
\hline
\end{tabular}

Strontium was found to be much higher than is usual in rocks, amounting to 0.3 per cent strontium oxide in several Waikato coal ashes. In ash from Mangapehi, an area south of the Waikato coalfield, the strontium content was found to be far above the amount usually determined spectrographically. A chemical determination revealed $1 \cdot 3$ per cent strontium oxide. The percentage was then confirmed by modifying the spectrographic method.

Further information is necessary before any conclusion as to the reason for these high concentrations can be put forward. It is significant that boron and strontium are relatively high in sea-water, and the high content of both may be connected in some way with contact of the coal measures with the sea. It must also be noted that the coals high in these constituents occur in hot spring or volcanic areas.

Coal Survey Division, T. A. RAFTER.

Dominion Laboratory, Wellington, N.Z.

${ }^{1}$ Goldschmidt, V. M., J. Chem. Soc., 655 (1937).

${ }^{2}$ Wilson, S. H., and Fieldes, M., N.Z. J. Sci. and Tech., 24, 98 (1942).

\section{Red Shift in the Anagalactic Nebulæ}

A рноток $h \nu$ emitted by a distant nebula toward our galaxy possesses a mass

$$
\mu=\frac{h \nu}{c^{2}} \quad \cdot \cdot \cdot \cdot
$$

and the equation for its energy is

$$
h \nu=\mu c^{2} \text {. }
$$

The mass $\mu$ of the photon is acted upon by the gravitational field of our galaxy, whatever this field may be : Newtonian, LeSagian ${ }^{1}$, or the relativistic curvature of space caused by the mass of the galaxy.

The law of gravitation requires that any mass in the field of our galaxy must be accelerated toward it. Therefore, using the inverse square law for falling bodies, the energy of the photon from the nebula we observe should be

$$
\begin{aligned}
h \nu=\mu\left[\sqrt{c^{2}+k\left(1-\frac{R}{A}\right)}\right]^{2}= \\
\mu\left[c^{2}+k\left(1-\frac{R}{A}\right)\right], .
\end{aligned}
$$

where $k=\frac{2 G M}{R}, R$ is radius of our galaxy (assuming 